\title{
Contents volume 14 (1996)
}

Health informatics education; an information-related undergraduate perspective D. Bawden

The influence of instruction and activity on the development of skills in the usage of interactive information systems

R. Oliver

Training in teamwork for students of Library and Information Studies

J. Hall

Fifty years of library education in Ghana and the challenges of restructuring M. Boye

Studies of librarianship and documentation in Spain (1978-1994) (Short communication)

A.-P. Ubieto, A. Sánchez Casabón and I. Ubieto

Improved practice and integrated skills in the LIS field. International Conference for the development of new ideas models and tools for the information profession. The Royal School of Librarianship, Copenhagen, Denmark 21-22 November 1995 (Short communication)

F. Guy

Book reviews

News

Editorial

B. Mahon

Monitoring and evaluating information-related research T.D. Wilson

Hypertext instructional programs and learner control: a research review A. Large

The multi-lingual information officer: educating European information professionals V. Couzinet

Qualitative research in information studies: a Malawian study

P. Sturges and G. Chimseu

Computers in Libraries International 96; a window to the library of the future, 20-22 Febrary 1996, Novotel Hammersmith, London, UK (Short communication) R.F. Guy

0167-8329/96/\$8.00 @ 1996- IOS Press 
Book reviews

Information for authors

The perceived prestige of professional journals, 1995: a replication of the Kohl-Davis study

V.L.P. Blake

Gender differences in the oral communication of technical information

R. Marcella and S.J. Binfield

Library and information science education in Saudi Arabia

M.A. Siddiqui

First steps: reconstructing library and information science education in South Africa P.G. Underwood and M.C. Nassimbeni

Focus groups: their use in LIS research data collection (Short communication)

E. Kerslake and A. Goulding

An information systems approach to teaching IT skills to students of library and information studies (Short communication)

M. Freeman and J. Rowley

Book reviews

News

Guest-editorial: Special issue on networked learner support

S. Fowell and P. Levy

NetLinkS: a national professional development project for networked learner support P. Levy, S.P. Fowell, N. Bowskill and E. Worsfold

"BCK2SKOL": a networked learning model classroom

E. Chamberlain and M.E. Mitchell

EDUCATE: the design and development of a networked end-user education program G. Thomasson and N. Fjällbrant

Towards a strategy for supporting distance-learning students through networked access to information: issues and challenges in preparing to support the Doctorate in Education

J. Carty, I. Stark, R. van der Zwan and N. Whitsed

The use of videoconferencing to support learning: an overview of issues relevant to the library and information profession

C. Cochrane

Support issues for case-based learning in an undergraduate human factors class K. Buckner and E. Davenport 
Role changes for the academic librarian to support effectively the networked learner: implications of the IMPEL Project

G. Walton, J. Day and C. Edwards

Book reviews

News

Author index volume 14

Contents volume 14 